\title{
Management justification and applications of the personal approach at the enterprise of the AIC
}

\author{
Oksana Lozovaya ${ }^{1}$, Alexey Martynushkin ${ }^{1}$, Irina Fedoskina $^{1}$, Oksana Vanyushina, Mihail \\ Polyakov ${ }^{1}$, and Nikolay Anikin ${ }^{1, *}$ \\ ${ }^{1}$ Ryazan State Agrotechnological University Named after P.A.Kostychev, Ryazan, Russia
}

\begin{abstract}
The theory and practice of management in the Russian Federation continues to transform and adapt in the context of the economic crisis and a high degree of uncertainty of external factors for enterprises of all industries and forms of ownership. The activity of a leader in an organization is associated with overcoming the problems of internal variable factors, the change of which is most often due to threats and the impact of the external environment. The classical postulates of management theory have been mastered and applied for a long period, but modern conditions of domestic enterprises require the development of new ones, simplification of complex ones and the addition of working methods to work with situations that help managers and specialists in achieving their goals and objectives. In this regard, the application of the most wellknown approaches in management is analyzed, an additional application of the personal approach is proposed, and its management rationale is given. Management at agro-industrial enterprises has specific features that are determined by characteristics of agriculture and problems of the national economy. Management activity at agro-industrial complex enterprises requires from managers high professionalism, great practical experience, selfless work, dedication to work and this industry. The developed approach will make it easier to carry out goal-setting, personally consolidate functions and tasks, delegate them according to the personal factor and the best performance, show a mixed management style focused on relationships and strategic goals.
\end{abstract}

\section{Introduction}

Modern research in the domestic science of management is based on many approaches that can be developed in most organizations, industries and spheres of activity. The most famous and widespread are such types of approaches in management theory as: process, system and situational ones. The process approach involves clear regulation of functional areas and types of management activities in an organization, the formation of standards, the development of appropriate performance indicators for each of the operations and work

* Corresponding author: kosta066@yandex.ru 
processes in general, application of scientific justification of the order and rules of organizational work.

In the middle of the last century, system and situational approaches were developed, which belonged to the modern school of management science, and also made a significant contribution to the development of management schools. The first of the above approaches identifies the system as a community or aggregate set of elements interconnected with each other, having "inputs: resources, purpose, information", "outputs: products, goods, works, services" and a block for converting inputs into outputs. Among disadvantages of using this approach is the tendency to introduce certain aspects or rules of the system approach, which are recognized as effective abroad, but do not bring the expected effect, in the current unique national economy of the Russian Federation. Therefore, many domestic leaders trust more the progressive experience of development and overcoming crises, methods and technologies that have been successfully implemented and have proven themselves domestically.

Within the framework of using the situational approach, such an algorithm can be distinguished, when the application of all management experience and its developments should be based on the conditions and specific variables of an individual organization, its situational factors, in relation to which the best way to resolve production and management tasks is selected. Many leaders point out that in the face of a rapidly changing external environment, it is difficult to follow the plans, since a lot of effort has to be made to solve urgent problems. All of the above approaches have been developed in agro-industrial production, but preliminary results and experience in the development of most agricultural enterprises show that the most successful ones in terms of key indicators are organizations with talented, professional leaders possessing strong and pronounced leadership qualities, who have embodied a career from a simple ordinary worker to a director. Modern management at an agro-industrial complex is positioned as the science, practice and art of managers to make operational and effective management decisions, including those aimed at overcoming the crisis in the organization.

\section{Materials and methods}

Scientific search and analysis of modern research in the framework of assessing the development of management of modern enterprises in the Russian Federation allows to conclude that currently it is necessary to revise and develop more advanced mechanisms that are adequate to the digital space and a more universal approach in terms of global trends. If a business is transferred to a global network, then there are always personal touch points of the source and destination, which are more equally responsible for the results of interaction. According to the materials of the Federal State Statistics Service, ambiguous conclusions can be made on the effectiveness of economic activities of agricultural enterprises in 2015-2019. Despite the decline in management standards of managers and the reduction of personnel in the crop and livestock sectors, a number of problems common for domestic agriculture for decades continue to intensify and complicate the development of management decisions, including crisis recovery. The general logic of the analysis of problems is such that a system approach implies a comprehensive plan and its implementation, affecting the full inclusion of elements, ranging from the highest level of the hierarchy (the Ministry of Agriculture of the Russian Federation) to the level of directly executors and all participants in the agro-industrial complex. A radical improvement of all elements at the same time is impossible, and, given the nature of the system engineering itself, it is impossible to leave individual elements without attention or change. It is necessary to improve everything in a complex and step by step, changing the environment that gives rise to these problems. 
The process approach is organic and viable, but in any duty regulations of managers and specialists of the agro-industrial complex, specific sections of functions related to a more in-depth look at the performance of work and immediate tasks of a particular manager are not indicated. That is, the construction of responsibilities and rights is too general and formal, without deciphering in detail those responsibilities that should be performed urgently, or in the case of delegation of authority to a superior leader. Individuals tend to remember 3-5 criteria best of all, for which they are stimulated or rewarded. The larger the list of what they have to do, the less the effectiveness and effect are. Therefore, each manager should be assigned exactly those functions that he will perform best, within the framework of the goals and objectives of the department, of course, without missing the strategic landmark of the entire agro-industrial complex.

The situational approach allows managers to solve certain production tasks and problems in the short term without fundamental improvement of the situation, relying mainly on the methods and style of leadership. Until recently, three styles of management (leadership) prevailed in Russian business: authoritarian, democratic, and liberal. Due to Soviet traditions and rules in management, most managers in domestic companies were characterized by strict authoritarianism, the desire to make all decisions on their own, lack of flexibility in management, and employees' initiatives were poorly encouraged. The managers were not and did not want to provide employees with more freedom, as they were accustomed to the established rules and hierarchy in the company, and it was considered unacceptable to change these principles. However, the previous generation is being replaced by new leaders $\mathrm{Y}$ and $\mathrm{Z}$, who have received modern business education. Many of them had internships, worked in European companies or abroad, saw and tried different management styles. Flexibility, partial involvement of employees in decision-making is already more common for the new type of managers. Of course, the leader is still distanced from his employees, but this is not the type of people who believe that there is only one correct point of view. A lot of research and concepts are reduced according to the research results to the fact that it is impossible to provide a universal description and application model for a single management style recommended for implementation at enterprises, including the agro-industrial complex. Each individual can take any traits he likes from any culture, Western or Eastern, considering it more authoritative and developed. A careful analysis of international news in terms of the management and development of companies allows to conclude that there are no longer any exclusive features in our societies.

Due to the topic under consideration, it is necessary to indicate a principle developed by practice that allows to achieve efficiency in managing a company in any industry. At the decision-making stage, the leader must be a democrat, that is, listen to all opinions and make the right decision, considering all aspects. Once a decision has been made, it is important to move to an authoritarian approach - the decision made should not be discussed. Thus, neither authoritarian nor democratic management styles can be effective individually, since they have corresponding advantages and disadvantages, and only in combination they give a good effect for the development of enterprises in the agroindustrial complex and other industries. Actually, a mixed management style of a manager focused on strategic goals, results and relations with personnel is capable of giving an innovative impetus to crisis recovery and systematic growth of the efficiency of the enterprise as a whole.

\section{Results}

The organizational and regulatory activities of the manager express the actual ability of the management subsystem to implement management decisions and effectively determine the actions of personnel, systematically showing that when achieving the goal and tasks of the 
enterprise, personal ideals and dreams come true. In this case, it still looks like a utopia in most domestic organizations, but the use of human capital, only as "working hands" is already a worldwide relic of the times. In general, the essence of the leadership style and performance of a manager consists in a combination of two approaches - depersonalization, defining the functions and competence of the position, and personal identification (in fact, a personal approach to the manager and other personnel), ensuring that the position corresponds to qualities and performed actions. The manager must perform as responsibly as possible, with a focus on the social and management function, harmonization and optimization, conduct not only his activities, but also delve into the work of his subordinates, identify the functions, competencies of the position, as well as their compliance with motives, psychological characteristics, abilities and professional characteristics of the personnel implementing them. Table 1 presents the comparative characteristics of the considered basic management approaches in comparison with personal management.

Table 1. Comparison of management approaches implemented at the enterprise.

\begin{tabular}{|c|c|c|c|c|}
\hline Criterion & Process & System & Situational & Personal \\
\hline $\begin{array}{l}\text { 1. Strategy } \\
\text { development }\end{array}$ & $\begin{array}{l}\text { Adapting } \\
\text { processes to } \\
\text { the type of } \\
\text { strategy }\end{array}$ & $\begin{array}{l}\text { The strategy } \\
\text { type is identical } \\
\text { to the enterprise } \\
\text { system }\end{array}$ & $\begin{array}{l}\text { Are not closely } \\
\text { related }\end{array}$ & $\begin{array}{l}\text { The more complex the } \\
\text { strategy, the more } \\
\text { personal } \\
\text { responsibility and } \\
\text { personal contribution } \\
\text { of top managers }\end{array}$ \\
\hline 2. Goal setting & $\begin{array}{l}\text { Functions } \\
\text { are designed } \\
\text { for the } \\
\text { general } \\
\text { purpose }\end{array}$ & $\begin{array}{l}\text { Goal setting - } \\
\text { system inputs, } \\
\text { accomplished } \\
\text { goals - outputs }\end{array}$ & $\begin{array}{l}\text { Situations are } \\
\text { solved } \\
\text { considering } \\
\text { production and } \\
\text { other needs } \\
\end{array}$ & $\begin{array}{l}\text { Mandatory structural } \\
\text { decomposition of the } \\
\text { general goal with the } \\
\text { distribution of tasks } \\
\text { by departments }\end{array}$ \\
\hline $\begin{array}{l}\text { 3. Functions } \\
\text { (powers) }\end{array}$ & $\begin{array}{l}\text { Primary and } \\
\text { formalized }\end{array}$ & $\begin{array}{l}\text { Are in the } \\
\text { relationship of } \\
\text { the object with } \\
\text { the subject }\end{array}$ & $\begin{array}{l}\text { Can be changed } \\
\text { subject to } \\
\text { situational } \\
\text { factors }\end{array}$ & $\begin{array}{l}\text { Developed for an } \\
\text { individual enterprise, } \\
\text { its managers and } \\
\text { specialists, clearly } \\
\text { distributed among } \\
\text { managers who are } \\
\text { able to fulfill them as } \\
\text { efficiently as possible }\end{array}$ \\
\hline $\begin{array}{l}\text { 4. Delegation } \\
\text { of power }\end{array}$ & Allowed & $\begin{array}{l}\text { Carried out } \\
\text { considering the } \\
\text { opinion of } \\
\text { senior managers }\end{array}$ & $\begin{array}{l}\text { Organizational } \\
\text { culture } \\
\text { accommodates } \\
\text { delegation of } \\
\text { authority due to } \\
\text { efficiency } \\
\text { dependence on } \\
\text { specific } \\
\text { delegation } \\
\text { models }\end{array}$ & $\begin{array}{l}\text { With an objective } \\
\text { knowledge of } \\
\text { properties and } \\
\text { qualities of the } \\
\text { individual (team } \\
\text { workers), the manager } \\
\text { understands which } \\
\text { performer can be } \\
\text { entrusted with the } \\
\text { performance of a } \\
\text { specific task }\end{array}$ \\
\hline $\begin{array}{l}\text { 5. Regulation } \\
\text { of } \\
\text { management } \\
\text { methods }\end{array}$ & $\begin{array}{l}\text { Are } \\
\text { interconnect } \\
\text { ed, used in } \\
\text { maximum } \\
\text { availability } \\
\text { and } \\
\text { spectrum }\end{array}$ & $\begin{array}{l}\text { The need for a } \\
\text { hierarchical } \\
\text { order implies } \\
\text { increased use of } \\
\text { administrative } \\
\text { and economic } \\
\text { methods }\end{array}$ & $\begin{array}{l}\text { A crisis } \\
\text { situation often } \\
\text { requires } \\
\text { administrative } \\
\text { and harsh } \\
\text { intervention }\end{array}$ & $\begin{array}{l}\text { Leans on a supportive } \\
\text { model of } \\
\text { organizational } \\
\text { behavior of personnel }\end{array}$ \\
\hline 6. & Correspondi & Obtaining & The methods & The applicant is \\
\hline
\end{tabular}




\begin{tabular}{|c|c|c|c|c|}
\hline $\begin{array}{l}\text { Management } \\
\text { technology }\end{array}$ & $\begin{array}{l}\text { ng functions } \\
\text { are } \\
\text { developed } \\
\text { and } \\
\text { prescribed } \\
\text { for each } \\
\text { position, } \\
\text { their } \\
\text { implementat } \\
\text { ion is } \\
\text { monitored }\end{array}$ & $\begin{array}{l}\text { information, } \\
\text { further exposure } \\
\text { and control }\end{array}$ & $\begin{array}{l}\text { that are most } \\
\text { suitable in } \\
\text { conditions of } \\
\text { the situation are } \\
\text { investigated, the } \\
\text { pros and cons of } \\
\text { their application } \\
\text { are evaluated }\end{array}$ & $\begin{array}{l}\text { examined for aptitude } \\
\text { for management, } \\
\text { performs a clearly } \\
\text { provided list of } \\
\text { functions, developed } \\
\text { for him personally, } \\
\text { reflecting fully the } \\
\text { specifics of the } \\
\text { enterprise and its } \\
\text { strategic guidelines }\end{array}$ \\
\hline $\begin{array}{l}\text { 7. Evaluation } \\
\text { of } \\
\text { effectiveness } \\
\text { (indicators) }\end{array}$ & $\begin{array}{l}\text { Separate } \\
\text { indicators } \\
\text { for each } \\
\text { function }\end{array}$ & $\begin{array}{l}\text { A set of } \\
\text { indicators } \\
\text { systematically } \\
\text { dependent on } \\
\text { each other }\end{array}$ & $\begin{array}{l}\text { One criterion or } \\
\text { indicators that } \\
\text { best suit the } \\
\text { situation } \\
\text { variables }\end{array}$ & $\begin{array}{l}\text { By the degree or } \\
\text { effectiveness of } \\
\text { achieving the set } \\
\text { goals }\end{array}$ \\
\hline $\begin{array}{l}8 . \\
\text { Motivational } \\
\text { components }\end{array}$ & $\begin{array}{l}\text { As one of } \\
\text { the common } \\
\text { managemen } \\
t \text { functions }\end{array}$ & $\begin{array}{l}\text { They are } \\
\text { considered in } \\
\text { the average } \\
\text { estimates for the } \\
\text { whole team, } \\
\text { fixed in the } \\
\text { regulations }\end{array}$ & $\begin{array}{l}\text { Used in a wider } \\
\text { range }\end{array}$ & $\begin{array}{l}\text { Systematic work is } \\
\text { built within the } \\
\text { framework of group } \\
\text { and individual } \\
\text { motivation of } \\
\text { personnel (provided } \\
\text { for by official } \\
\text { regulations) }\end{array}$ \\
\hline $\begin{array}{l}\text { 9. Style } \\
\text { (management) } \\
\text {, leadership }\end{array}$ & $\begin{array}{l}\text { Focused on } \\
\text { completing } \\
\text { tasks }\end{array}$ & Result oriented & $\begin{array}{l}\text { Solves } \\
\text { situational } \\
\text { factors, } \\
\text { problems in the } \\
\text { most effective } \\
\text { way }\end{array}$ & $\begin{array}{l}\text { Personal and } \\
\text { professional } \\
\text { predisposition to } \\
\text { management } \\
\text { activities, focus on all } \\
\text { categories }\end{array}$ \\
\hline $\begin{array}{l}\text { 10. Industry } \\
\text { specifics }\end{array}$ & $\begin{array}{l}\text { Not } \\
\text { considered, } \\
\text { versatility of } \\
\text { basic } \\
\text { functions }\end{array}$ & $\begin{array}{l}\text { Defines directly } \\
\text { the system and } \\
\text { subsystems }\end{array}$ & $\begin{array}{l}\text { Depends on the } \\
\text { method of } \\
\text { application and } \\
\text { parameters of } \\
\text { situations }\end{array}$ & $\begin{array}{l}\text { The leader must go } \\
\text { through all the } \\
\text { hierarchy levels in the } \\
\text { industry before being } \\
\text { elected or promoted to } \\
\text { a senior position }\end{array}$ \\
\hline $\begin{array}{l}11 . \\
\text { Communicati } \\
\text { on process }\end{array}$ & $\begin{array}{l}\text { Supported } \\
\text { during the } \\
\text { implementat } \\
\text { ion of } \\
\text { functions }\end{array}$ & $\begin{array}{l}\text { Should be lined } \\
\text { up between all } \\
\text { elements }\end{array}$ & $\begin{array}{l}\text { Can be } \\
\text { organized as a } \\
\text { single episode } \\
\text { or event }\end{array}$ & $\begin{array}{l}\text { Necessary process of } \\
\text { interaction between } \\
\text { line and functional } \\
\text { levels, with } \\
\text { mandatory feedback }\end{array}$ \\
\hline
\end{tabular}

The comparison is given according to the criteria that are ranked in the order of their development in the enterprise. Strategy development and goal-setting are closely interconnected, and also act as a key vector of management at a medium or large agricultural enterprise. In many organizations, there has been an optimization of the personnel structure, considering individual functional responsibilities and assigning them to appropriate managers. Thus, the organizational and target structure of the agro-industrial complex enterprise, considering the specific functions being developed, is shown in Figure 1. 


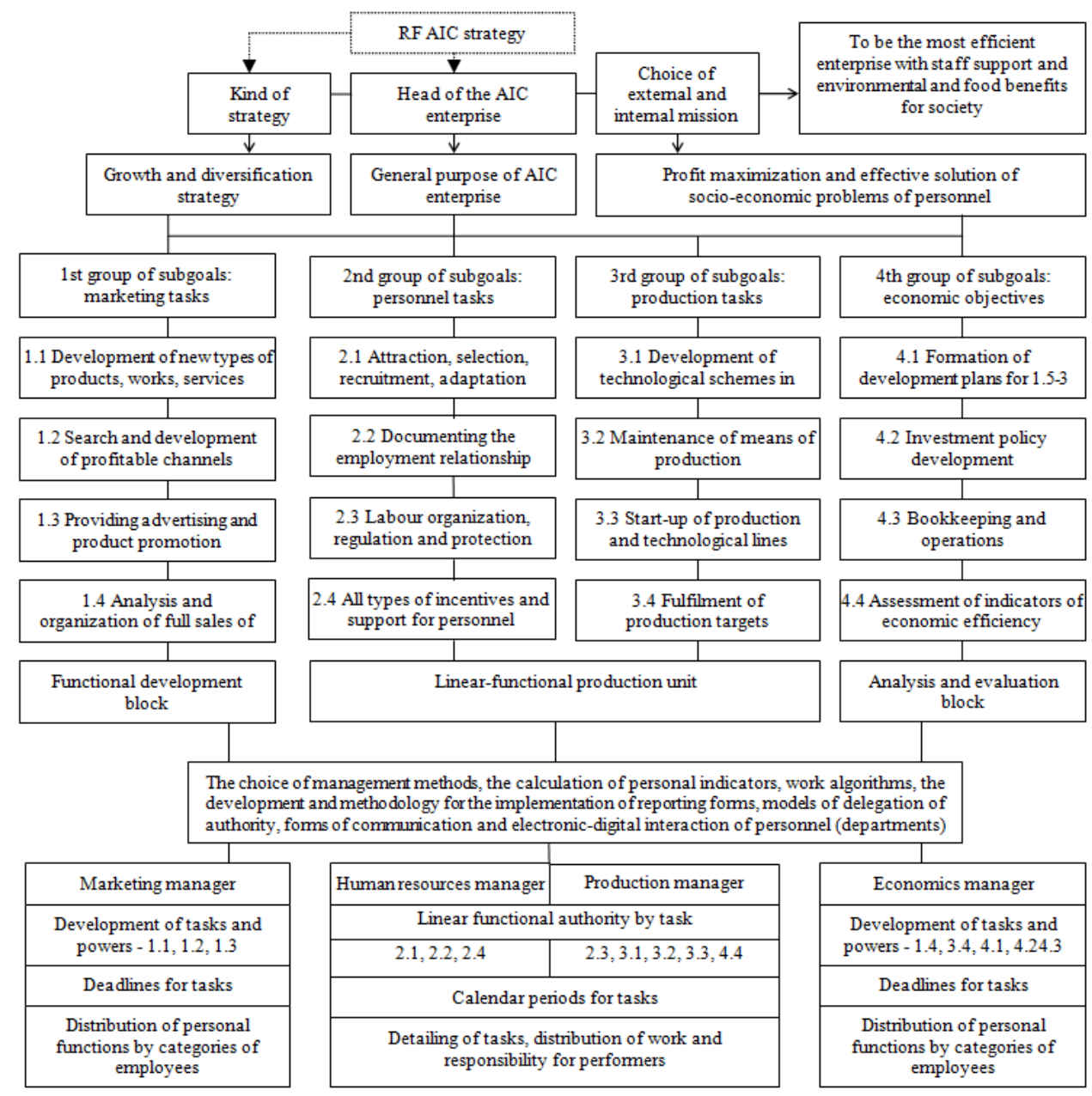

Fig. 1. The fundamentals of the organizational and target structure of an agro-industrial complex enterprise, considering a personal approach to management functions (a variant of the structure).

\section{Conclusion}

The theory and practice of management according to different classifications has from 3 to 15 approaches to the implementation of management at the enterprise. At the enterprises of the agro-industrial complex, as in all other organizations of all industries and forms of ownership, to the greatest extent, the process, system and situational approaches are used. The practical successful experience of profitable agribusiness enterprises is characterized by simplified procedures in comparison with the theoretical concept of management, as well as by the presence of an advanced professional leader, a director, who manages the industry, who is able to build a personal approach and leadership style in such a way as to strategically develop correctly not only the main industries, but also additional, auxiliary, as well as promptly counteract crisis phenomena.

Most of the theories and models of delegation of authority in the Russian Federation are not implemented, since a manager spends a significant part of his working time on overcoming unforeseen situations and assessing environmental factors in the country is 
associated with a very high risk of uncertainty. Therefore, the manager cannot entrust part of responsibilities to the subordinate employee, because he himself does not know yet what problems he will eventually face. In this case, a personal approach may also be more effective, since the manager must understand who of assistants can cope and personally answer for the delegated assignment more adequately and professionally. At the same time, when managing such departments of an enterprise as marketing, personnel, advertising, a democratic model can be more effective, since these are more creative spheres of activity, where the collective opinion of a number of narrowly focused specialists is often required to find the best solution. In this sense, each specialist should know his area better than the leader, so it makes sense to listen to their opinion and delegate authority, sharing responsibility. Moreover, if the issue goes beyond any one area, then the decisive word should remain with the leader, because the specialist decides his / her respective issue, and the leader determines the entire situation and results in combination with strategic consequences.

\section{References}

1. O.I. Vanyushina, Bulletin of the Ryazan State Agrotechnological University named after P. A. Kostychev 3, 62-65 (2014)

2. N.G. Uskov, O.V. Lozova, The International Scientific and Practical Congress of Economists and Jurists "The global systemic crisis new mileston in development or an impasse?" (Geneva, International scientific Association of economists "Consilium", 2015)

3. V.S. Konkina, A.B. Martynushkin, International Transaction Journal of Engineering, Management and Applied Sciences and Technologies 11(10), 11A10L (2020)

4. A.B. Martynushkin, V.S. Konkina, J.B. Kostrova et al., Modern Trends in Agricultural Production in the World Economy, 77-84 (2020)

5. N. Anikin, V. Terentyev, K. Andreev et al., Journal of Physics: Conference Series, 012094 (2020)

6. A.B. Martynushkin, V.S. Konkina, Advances in Economics, Business and Management Research. Proceedings of the Russian Conference on Digital Economy and Knowledge Management (RuDEcK 2020), 449-455 (2020)

7. A.B. Martynushkin, Yu.B. Kostrova, Yu.O. Lyashchuk, Bulletin of KrasGAU 6(162), 157-164 (2020)

8. I.G. Shashkova, L.V. Romanova, S.V. Kornilov et al., BIO Web of Conferences 2019 17, 00087 (2020)

9. G. Bakulina, G. Kalinina, I. Luchkova et al., BIO Web of Conferences 2019 17, 00188 (2020)

10. V. Konkina, BIO Web of Conferences 2019 17, 00086 (2020)

11. G. Bakulina, V. Fedoskin, M. Pikushina et al., International Journal of Circuits, Systems and Signal Processing 14, 232-240 (2020)

12. E.P. Polikarpova, I.E. Mizikovskiy, E3S Web of Conferences: International Scientific and Practical Conference «Development of the Agro-lndustrial Complex in the Context of Robotization and Digitalization of Production in Russia and Abroad» 222, 06007 (2020)

13. V. Konkina, A. Shemyakin, I. Babkin, Proceedings of the 33rd International Business Information Management Association Conference, IBIMA 2019: Education Excellence and Innovation Management through Vision 2020, 8632-8637 (2019) 
14. E.P. Polikarpova, I.E. Mizikovskiy, Custos e Agronegocio 15, 2-17 (2019)

15. E.P. Polikarpova, I.E. Mizikovskiy, Custos e Agronegocio 14(4), 149-166 (2018)

16. E.P. Polikarpova, I.E. Mizikovskiy, BIO Web of Conferences 17, 00124 (2019)

17. F.I. Mirzabalaeva, O.V. Zabelina, P.R. Alieva et al., Academy of Strategic Management Journal 16(1), 132-148 (2018)

18. N.V. Byshov, L.N. Lazutkina, V.S. Konkina et al., Dilemas contemporaneos-educacion politica y valores 6, 107 (2019)

19. V. Fedoskin, G. Bakulina, M. Pikushina, E3S Web of Conferences: International Scientific and Practical Conference "Development of the Agro-Industrial Complex in the Context of Robotization and Digitalization of Production in Russia and Abroad» 222, 06020 (2020)

20. K. Andreev, V. Terentyev, A. Shemyakin, XII International Scientific Conference on Agricultural Machinery Industry IOP Conf. Series: Earth and Environmental Science 403, 012180 (2019)

21. Zavgorodnyaya, A.S., Shashkova, I.G., Konkina, V.S. et al., Journal of Advanced Research in Dynamical and Control Systems 7, 2022-2031 (2018) 